Article

\title{
Activity of Salvia dolomitica and Salvia somalensis Essential Oils against Bacteria, Molds and Yeasts
}

\author{
Valentina Virginia Ebani ${ }^{1,2}$, , Simona Nardoni ${ }^{1,2}$, Fabrizio Bertelloni ${ }^{1}$, Silvia Giovanelli ${ }^{3}$, \\ Barbara Ruffoni ${ }^{4}$, Carlo D'Ascenzi ${ }^{1}$, Luisa Pistelli ${ }^{2,3}$ and Francesca Mancianti ${ }^{1,2}$ \\ 1 Department of Veterinary Science, University of Pisa, Viale delle Piagge 2, 56124 Pisa, Italy; \\ simona.nardoni@unipi.it (S.N.); fabrizio.bertelloni@vet.unipi.it (F.B.); carlo.dascenzi@unipi.it (C.D.); \\ francesca.mancianti@unipi.it (F.M.) \\ 2 Centro Interdipartimentale di Ricerca "Nutraceutica e Alimentazione per la Salute", University of Pisa, \\ Via del Borghetto 80, 56124 Pisa, Italy; luisa.pistelli@unipi.it \\ 3 Department of Pharmacy, University of Pisa, Via Bonanno 6, 56126 Pisa, Italy; silvia.giovanelli84@gmail.com \\ 4 Centro di Ricerca Orticoltura e Florovivaismo (CREA), Corso Degli Inglesi 508, 18038 Sanremo, Italy; \\ barbara.ruffoni@entecra.it \\ * Correspondence: valentina.virginia.ebani@unipi.it; Tel.: +39-05-0221-6968
}

Received: 13 December 2017; Accepted: 9 February 2018; Published: 13 February 2018

\begin{abstract}
Essential oils (EOs) from Salvia dolomitica and Salvia somalensis, widely employed in the cosmetic and perfume industry, were analyzed for composition and tested against bacterial and fungal pathogens isolated from clinical and environmental specimens. The analyses were carried out against Staphylococcus aureus, Staphylococcus pseudointermedius, Pseudomonas aeruginosa, Escherichia coli, Streptococcus canis, Streptococcus pyogenes, Klebsiella pneumoniae, Proteus mirabilis, Microsporum canis, Microsporum gypseum, Trichophyton mentagrophytes, Aspergillus niger, Aspergillus flavus, Candida albicans, Candida krusei, Mucor sp. and Trichothecium roseum. Both EOs showed similar percentages of total monoterpenes and sesquiterpene hydrocarbons. The main constituents were 1,8-cineole and $\beta$-caryophyllene in S. dolomitica and bornyl acetate and camphor in S. somalensis. The selected EOs have no relevant antifungal or antibacterial activities if compared to conventional drugs.
\end{abstract}

Keywords: Salvia dolomitica; Salvia somalensis; antibacterial activity; antifungal activity

\section{Introduction}

The genus Salvia belongs to the family Lamiaceae and includes about 900 species spread throughout the world. Taxa of Salvia spp. (sage) are mainly aromatic plants, rich in essential oils (EOs) and widely employed in foods, perfumery and cosmetics [1]. EOs from Salvia spp. are rich in monoterpene hydrocarbons $(\mathrm{MH})$, oxygenated monoterpenes $(\mathrm{OM})$ and sesquiterpenes [2].

Natural products isolated from Salvia spp. have long been used in traditional medicine to treat several microbial afflictions [2], but considering the high number of species of this genus, the antimicrobial properties of all of them is not well known. Salvia dolomitica Codd and Salvia somalensis Vatke are two species native to Africa. The first sage is an aromatic perennial shrub able to grow on heavy soils with dolomitic rocks. EO from S. dolomitica has been suggested as an antiplasmodial and antiinflammatory remedy. Its antimicrobial activity against some bacteria has been described [3]. S. somalensis is a wild sage native to Somalia. A potential cosmetic application of its EO has been proposed for its peculiar olfactive characters [4], but data about its antimicrobial activity are not available in the scientific literature. Considering that EOs from these botanical species are already employed, the aim of the present investigation was to verify the activity of EOs from S. dolomitica and S. somalensis against bacterial and fungal pathogens previously isolated from clinical and environmental 
specimens. These organisms were selected for their relevance in veterinary practice and/or in foodstuff preservation.

\section{Results}

\subsection{EO Analysis}

The EOs' composition is reported in Table 1. A total of 59 compounds were characterized, with identification percentages ranging from $98.5 \%$ in S. somalensis to $98.9 \%$ in S. dolomitica. The monoterpenes class was the most abundant in both samples $(73.1 \%$ in S. dolomitica and $67.8 \%$ in S. somalensis). 1,8-Cineole was the main constituent in S. dolomitica (18.9\%), while bornyl acetate $(16.1 \%)$ together with camphor $(12.5 \%)$, showed the highest percentage in S. somalensis. Among the sesquiterpenes, sesquiterpene hydrocarbons ( $\mathrm{SH}$ ) exhibited a higher relative amount in comparison with the oxygenated sesquiterpenes (OS) in both samples. $\beta$-Caryophyllene predominated in S. dolomitica (13.1\%) and $\delta$-cadinene in the other sage sample $(6.4 \%)$.

Table 1. EO analysis of Salvia dolomitica and Salvia somalensis aerial parts.

\begin{tabular}{|c|c|c|c|c|c|}
\hline \multirow{2}{*}{ No. } & \multirow{2}{*}{ Class } & \multirow{2}{*}{ Component } & \multirow{2}{*}{ L.R.I. $\S$} & \multicolumn{2}{|c|}{ Relative Content (\%) } \\
\hline & & & & S. dolomitica & S. somalensis \\
\hline 1 & $\mathrm{MH}$ & $\alpha$-Thujene & 930 & 0.25 & $\operatorname{tr}$ \\
\hline 2 & $\mathrm{MH}$ & Tricyclene & 932 & 0.10 & $\operatorname{tr}$ \\
\hline 3 & $\mathrm{MH}$ & $\alpha$-Pinene & 939 & 9.60 & 9.28 \\
\hline 4 & MH & Camphene & 955 & 5.23 & 8.04 \\
\hline 5 & MH & Sabinene & 978 & & 0.77 \\
\hline 6 & $\mathrm{MH}$ & $\beta$-Pinene & 981 & 1.31 & \\
\hline 7 & MH & Myrcene & 993 & 2.73 & 1.23 \\
\hline 8 & MH & $\delta$-2-Carene & 1002 & 6.68 & 6.29 \\
\hline 9 & $\mathrm{MH}$ & $\alpha$-Phellandrene & 1006 & 0.82 & 0.47 \\
\hline 10 & MH & $\alpha$-Terpinene & 1019 & 0.95 & 0.48 \\
\hline 11 & $\mathrm{MH}$ & p-Cymene & 1025 & 1.55 & 1.55 \\
\hline 12 & $\mathrm{MH}$ & Limonene & 1032 & 8.94 & 4.62 \\
\hline 13 & $\mathrm{OM}$ & 1,8-Cineole & 1036 & 18.91 & $\operatorname{tr}$ \\
\hline 14 & $\mathrm{MH}$ & ( $Z$ )- $\beta$-Ocimene & 1037 & 2.66 & $\operatorname{tr}$ \\
\hline 15 & $\mathrm{MH}$ & (E)- $\beta$-Ocimene & 1053 & 0.39 & $\operatorname{tr}$ \\
\hline 16 & $\mathrm{MH}$ & $\gamma$-Terpinene & 1058 & 1.13 & 0.47 \\
\hline 17 & $\mathrm{MH}$ & para-Mentha-2,4(8)-diene & 1088 & 0.39 & 0.14 \\
\hline 18 & $\mathrm{MH}$ & Terpinolene & 1090 & 0.21 & 0.74 \\
\hline 19 & $\mathrm{OM}$ & Linalool & 1102 & 0.17 & 0.23 \\
\hline 20 & $\mathrm{OM}$ & trans-Thujone & 1117 & 0.10 & \\
\hline 21 & $\mathrm{OM}$ & Camphor & 1148 & & 12.52 \\
\hline 22 & $\mathrm{OM}$ & Borneol & 1169 & 6.57 & 2.79 \\
\hline 23 & $\mathrm{OM}$ & 4-Terpineol & 1180 & 0.59 & 0.67 \\
\hline 24 & $\mathrm{OM}$ & $\alpha$-Terpineol & 1192 & 0.11 & 1.26 \\
\hline 25 & NT & (Z)-Butanoic acid & 1236 & 0.12 & \\
\hline 26 & $\mathrm{OM}$ & Bornyl acetate & 1289 & & 16.15 \\
\hline 27 & $\mathrm{SH}$ & $\alpha$-Cubebene & 1351 & 0.20 & 0.31 \\
\hline 28 & $\mathrm{SH}$ & Cyclosativene & 1371 & & 0.68 \\
\hline 29 & $\mathrm{SH}$ & Isoledene & 1376 & 0.31 & \\
\hline 30 & $\mathrm{SH}$ & $\alpha$-Copaene & 1377 & 1.69 & 3.46 \\
\hline 31 & $\mathrm{OM}$ & ( Z)-Jasmone & 1397 & & 0.10 \\
\hline 32 & SH & Cyperene & 1399 & 0.55 & \\
\hline 33 & SH & $\alpha$-Gurjunene & 1410 & & 0.89 \\
\hline 34 & $\mathrm{SH}$ & $\beta$-Caryophyllene & 1418 & 13.12 & 4.52 \\
\hline 35 & $\mathrm{SH}$ & $\beta$-Gurjunene & 1434 & 0.62 & 0.19 \\
\hline 36 & SH & $\alpha$-Guaiene & 1440 & 0.46 & 1.37 \\
\hline 37 & $\mathrm{SH}$ & cis-Muurola-3,5-diene & 1450 & & 0.11 \\
\hline 38 & $\mathrm{OM}$ & trans-Carvyl propanoate & 1455 & 3.68 & \\
\hline
\end{tabular}


Table 1. Cont.

\begin{tabular}{|c|c|c|c|c|c|}
\hline \multirow{2}{*}{ No. } & \multirow{2}{*}{ Class } & \multirow{2}{*}{ Component } & \multirow{2}{*}{ L.R.I. ${ }^{\S}$} & \multicolumn{2}{|c|}{ Relative Content (\%) } \\
\hline & & & & S. dolomitica & S. somalensis \\
\hline 39 & $\mathrm{SH}$ & $\alpha$-Humulene & 1456 & 1.08 & 0.35 \\
\hline 40 & $\mathrm{SH}$ & allo-Aromadendrne & 1460 & 0.31 & 0.43 \\
\hline 41 & $\mathrm{SH}$ & trans-Cadina-1(6),4-diene & 1477 & 0.35 & 0.59 \\
\hline 42 & $\mathrm{SH}$ & $\gamma$-Muurolene & 1480 & 0.37 & 0.78 \\
\hline 43 & SH & $\gamma$-Curcumene & 1481 & & 0.24 \\
\hline 44 & $\mathrm{SH}$ & Germacrene D & 1484 & & 0.5 \\
\hline 45 & $\mathrm{SH}$ & $\beta$-Selinene & 1490 & 0.21 & 0.1 \\
\hline 46 & $\mathrm{SH}$ & cis- $\beta$-Guaiene & 1493 & 0.13 & 0.17 \\
\hline 47 & $\mathrm{SH}$ & Valencene & 1496 & 1.43 & 0.73 \\
\hline 48 & $\mathrm{SH}$ & Viridiflorene & 1497 & 0.51 & \\
\hline 49 & $\mathrm{SH}$ & trans- $\beta$-Guaiene & 1503 & & 0.88 \\
\hline 50 & $\mathrm{SH}$ & trans- $\gamma$-Cadinene & 1513 & 1.35 & 3.11 \\
\hline 51 & $\mathrm{SH}$ & $\delta$-Cadinene & 1523 & 2.54 & 6.43 \\
\hline 52 & $\mathrm{SH}$ & trans-Cadina-1(2),4-diene & 1535 & 0.24 & 0.56 \\
\hline 53 & $\mathrm{SH}$ & $\alpha$-Cadinene & 1539 & 0.10 & 0.25 \\
\hline 54 & $\mathrm{SH}$ & $\alpha$-Calacorene & 1546 & $\operatorname{tr}$ & 0.37 \\
\hline 55 & OS & trans-Nerolidol & 1566 & & 0.64 \\
\hline 56 & OS & Caryophyllene oxide & 1583 & & 0.14 \\
\hline 57 & OS & 1- epi-Cubenol & 1630 & $\operatorname{tr}$ & 0.66 \\
\hline 58 & OS & Hinesol & 1638 & 0.14 & 1.99 \\
\hline 59 & OS & Cubenol & 1641 & & 0.21 \\
\hline \multicolumn{4}{|c|}{ Non terpenic compounds (NT) } & 0.12 & 0.00 \\
\hline \multicolumn{4}{|c|}{ Monoterpene hydrocarbons (MH) } & 42.94 & 34.08 \\
\hline \multicolumn{4}{|c|}{ Oxygenated monoterpenes (OM) } & 30.13 & 33.72 \\
\hline \multicolumn{4}{|c|}{ Total monoterpenes (TM) } & 73.07 & 67.80 \\
\hline \multicolumn{4}{|c|}{ Sesquiterpene hydrocarbons (SH) } & 25.57 & 27.02 \\
\hline \multicolumn{4}{|c|}{ Oxygenated sesquiterpenes (OS) } & 0.14 & 3.64 \\
\hline \multicolumn{4}{|c|}{ Total sesquiterpenes (TS) } & 25.71 & 30.66 \\
\hline \multicolumn{4}{|c|}{ Total identified } & 98.90 & 98.46 \\
\hline
\end{tabular}

\subsection{Antibacterial Activity}

\subsubsection{Agar Disk Diffusion Method}

The agar disk diffusion method showed that EO from S. somalensis did not inhibit any tested bacterial isolate; conversely S. dolomitica EO had a low effectiveness at $10 \%$ dilution (MIC $16.26 \mathrm{mg} / \mathrm{mL}$ ) against Streptococcus canis, Klebsiella pneumoniae and Proteus mirabilis. No inhibition zone was observed for the negative control. Results of the Kirby-Bauer assay are reported in Table 2.

Table 2. Results (inhibition zone expressed in $\mathrm{mm}$ ) of the Kirby-Bauer assay testing the selected bacterial strains against four antibiotics.

\begin{tabular}{|c|c|c|c|c|}
\hline \multirow[b]{2}{*}{ Bacterial Strains } & \multirow[b]{2}{*}{ Amikacin } & \multicolumn{3}{|c|}{ Antibiotics $(30 \mu \mathrm{g})$} \\
\hline & & Amoxycillin + Clavulanic Acid & Cefotaxime & Tetracycline \\
\hline Staphylococcus aureus & $18(S)$ & $20(S)$ & $16(\mathrm{I})$ & $12(\mathrm{R})$ \\
\hline Staphylococcus pseudointermedius & $19(S)$ & $21(S)$ & $23(S)$ & $11(\mathrm{R})$ \\
\hline Streptococcus canis & $19(S)$ & $21(S)$ & $23(S)$ & $20(S)$ \\
\hline Streptococcus pyogenes & $20(S)$ & $23(S)$ & $23(S)$ & $20(S)$ \\
\hline Pseudomonas aeruginosa & $12(\mathrm{R})$ & $20(S)$ & $17(\mathrm{I})$ & $12(\mathrm{R})$ \\
\hline Escherichia coli & $13(\mathrm{R})$ & $22(S)$ & $25(S)$ & $21(\mathrm{~S})$ \\
\hline Proteus mirabilis & $20(S)$ & $22(S)$ & $24(S)$ & $20(S)$ \\
\hline Klebsiella pneumoniae & $15(\mathrm{I})$ & $20(S)$ & $24(S)$ & $10(\mathrm{R})$ \\
\hline
\end{tabular}

Legend-S: susceptible; R: resistant; I: intermediate. Breakpoint values: amikacin $\leq 14 \mathrm{~mm} \mathrm{R}, 15-16 \mathrm{~mm} \mathrm{I}$, $\geq 17 \mathrm{~mm} \mathrm{~S}$; amoxicillin + clavulanic acid $\leq 19 \mathrm{~mm} \mathrm{R}$ (staphylococci), $\leq 13 \mathrm{~mm} \mathrm{R}$ (remaining bacteria), $14-17 \mathrm{~mm}$ $\mathrm{I}, \geq 20 \mathrm{~mm}$ (staphylococci) $\mathrm{S}, \geq 18 \mathrm{~mm}$ (remaining bacteria) S; cefotaxime $\leq 14 \mathrm{~mm} \mathrm{R}, 15-22 \mathrm{~mm} \mathrm{I}, \geq 23 \mathrm{~mm} \mathrm{~S}$; tetracycline $\leq 14 \mathrm{~mm} \mathrm{R}, 15-18 \mathrm{~mm} \mathrm{I}, \geq 19 \mathrm{~mm} \mathrm{~S}$. 


\subsubsection{Minimum Inhibitory Concentration}

Similar results were obtained by the broth microdilution method. In fact, MIC values of $16.26 \mathrm{mg} / \mathrm{mL}$ were observed when S. dolomitica EO was tested against S. canis, K. pneumoniae and P. mirabilis, whereas bacterial growth was found for the remaining isolates. All bacterial strains were not inhibited by $S$. somalensis $\mathrm{EO}$. Bacterial growth was observed when bacteria had been incubated with brain hearth infusion broth (BHIB, Oxoid Ltd., Basingstoke, Hampshire, UK) without EOs, whereas it was not detected in the sterility control wells.

\subsection{Antifungal Activity}

The examined EOs showed variable degrees of antimycotic activity towards tested fungal isolates. From a general point of view, molds appeared more prone to the selected EOs rather than yeasts. Microsporum gypseum appeared to be the most sensitive fungal species, inhibited by $1.70 \mathrm{mg} / \mathrm{mL}$ of $S$. somalensis EO with $\mathrm{IC}_{50}$ 0.84. Moreover, Mucor sp. and Trichothecium roseum did not show a visible growth at $4.06 \mathrm{mg} / \mathrm{mL}$ ( $\mathrm{IC}_{50} 2.07$ ) of $S$. dolomitica, and $5.11 \mathrm{mg} / \mathrm{mL}\left(\mathrm{IC}_{50} 4.42\right)$ of S. somalensis, respectively. Candida spp. and Aspergillus spp. employed were susceptible to selected conventional drugs. Mycotic growth was observed in negative control wells (without EOs). All the results of EOs and results of conventional drugs, with available clinical breakpoints are reported in Table 3.

Table 3. Results of microdilution assay testing S. somalensis and S. dolomitica EOs and conventional antimycotic drugs against fungal strains from different sources.

\begin{tabular}{|c|c|c|c|c|c|c|c|}
\hline \multirow[b]{3}{*}{ Fungal Strains } & \multirow{3}{*}{$\begin{array}{l}\text { Source of } \\
\text { Isolates }\end{array}$} & \multicolumn{4}{|c|}{ Essential Oils } & \multirow{3}{*}{$\begin{array}{l}\text { Conventional } \\
\text { Drugs (mg/mL) }\end{array}$} & \multirow{3}{*}{$\begin{array}{c}\text { CLSI } \\
\text { Clinical } \\
\text { Breakpoint }\end{array}$} \\
\hline & & \multicolumn{2}{|c|}{ S. somalensis } & \multicolumn{2}{|c|}{ S. dolomitica } & & \\
\hline & & $\begin{array}{c}\text { MIC } \\
(\mathrm{mg} / \mathrm{mL})\end{array}$ & $\begin{array}{c}\mathrm{IC}_{50} \\
(\mathrm{mg} / \mathrm{mL})\end{array}$ & $\begin{array}{c}\text { MIC } \\
(\mathrm{mg} / \mathrm{mL})\end{array}$ & $\begin{array}{c}\mathrm{IC}_{50} \\
(\mathrm{mg} / \mathrm{mL})\end{array}$ & & \\
\hline Microsporum canis & feline hair & 17.04 & 12.8 & 16.26 & 11.62 & $\operatorname{ITZ}(0.125)$ & - \\
\hline Microsporum gypseum & feline hair & 1.70 & 0.84 & 4.88 & 4.26 & ITZ (32) & - \\
\hline Trichophyton mentagrophytes & canine hair & 17.04 & 12.8 & 16.26 & 11.62 & ITZ (32) & - \\
\hline Candida albicans & canine feces & 17.04 & 12.8 & 16.26 & 11.62 & $\operatorname{FLU}\left(0.25 \times 10^{-3}\right)$ & 8 \\
\hline Candida krusei & canine feces & 17.04 & 12.8 & 16.26 & 11.62 & $\mathrm{AmB}(0.5)$ & 1 \\
\hline Mucor sp. & environment & 8.52 & 7.84 & 4.06 & 2.07 & $\mathrm{AmB}(0.5)$ & - \\
\hline Trichothecium roseum & environment & 5.11 & 4.42 & 8.13 & 4.48 & Thiabendazole (4) & - \\
\hline
\end{tabular}

Legend-ITZ: itraconazole; FLU: Fluconazole; AmB: Amphotericine B; CSP: Caspofungin.

\section{Discussion}

S. dolomitica Codd is an aromatic perennial shrub, native of the North-East province of Transvaal in Southern Africa. The species name refers to its frequent occurrence on soil with dolomite rock. This sage is highly scented and drought resistant [5]. S. dolomitica is mainly commercialized for ornamental purposes and can be cultivated in pots and used as groundcover, shrub border or edging [6].

Fisher [7] and Kamatou et al. [8] characterized EOs from fresh aerial parts of S. dolomitica Codd grown in open fields in South Africa. The comparison between the analysis of the EO obtained from S. dolomitica grown in the Cape region of South Africa and our plant collected in Sanremo (Italy) showed a different behaviour, since the South African sample had a high percentage of geraniol $(19.6 \%)$ and linalyl acetate (19.6\%), totally absent in our sample, followed by linalool and $\alpha$-terpineol $(16.6 \%$ and $6.2 \%$, respectively) [8]. The composition of our S. dolomitica EO also differed from the other South African sample [7] for the amounts of main constituents. In detail South African sample was composed of $17.6 \%$ of $\beta$-caryophyllene, $17.4 \%$ of 1,8 -cineole, $9.7 \%$ of limonene, $8.5 \%$ of borneol, $7.5 \%$ of $\delta-3$ carene and $7.1 \%$ of $\alpha$-pinene. S. dolomitica EO of the present study showed almost the same compounds in different amounts: $18.9 \%$ of 1,8 -cineole, $13.2 \%$ of $\beta$-caryophyllene, $9.6 \%$ of $\alpha$-pinene, $8.9 \%$ of limonene, $6.7 \%$ of $\delta-2$ carene, $6.6 \%$ of borneol and $5.2 \%$ camphene.

S. somalensis Vatke EO, recovered after hydrodistillation of the dried aerial parts, has its main practical application in the cosmetic industry. This taxon is a wild plant native to Somalia, where it 
grows in full sun to partial shade. S. somalensis is characterized by a pleasant fragrance and it is well known as easy-to-grow ornamental plant especially in dry gardens, due to its drought tolerance [4]. The EO obtained from S. somalensis showed a chemical profile very similar to that reported by Villa et al. [4]. However $\delta$-cadinene and $\alpha$-copaene had higher percentages in our sample $(6.43 \%$ versus $0.26 \%$ and $3.46 \%$ versus $1.43 \%$, respectively).

To the best of our knowledge no studies about the antimicrobial activity of $S$. somalensis are reported in the scientific literature. In the present paper, $S$. somalensis was ineffective against all the tested bacterial strains, while $S$. dolomitica had a very low activity against $S$. canis, K. pneumoniae and P. mirabilis.

The EOs examined in the present study are characterized by different composition, apart from their content in $\alpha$-pinene. Bornyl acetate and camphor were the main constituents in $S$. somalensis, compounds totally absent in $S$. dolomitica EO, where 1,8-cineole and $\beta$-caryophyllene showed the highest percentages. These pure compounds are known to be active as antimicrobial agents $[9,10]$.

Little information is available about the antimicrobial activity of S. dolomitica. Fisher [7] reported a slight activity of $S$. dolomitica $\mathrm{EO}$ against Bacillus cereus, but not against Escherichia coli, S. aureus, K. pneumoniae and Yersinia enterocolitica.

Previous investigations on other Salvia spp. reported antimicrobial activity of Salvia sclarea EO against P. aeruginosa and mainly S. pseudointermedius [11], whereas S. dolomitica and S. somalensis EOs tested herein had no inhibition activity against these bacterial strains.

On the basis of the results obtained in previous studies, Gram positive bacteria would seem to be more sensitive to Salvia spp. EOs than Gram negative bacteria [12,13]. The present investigation does not confirm this hypothesis, because inhibition activity of $S$. dolomitica was observed against both Gram positive (S. canis) and Gram negative (K. pneumoniae and P. mirabilis) bacteria.

All the tested bacteria used in this work were clinical isolates. In fact, these species can be frequently found in cases of septicemia and infections of ears, skin, genitourinary and gastrointestinal tracts. Treatment with antibiotics is usually performed, even though the infection's resolution is not obtained in some cases because of the antibiotic-resistance of the etiologic agents.

To the best of our knowledge this is the first study dealing with the antimycotic activity of these Salvia species. The antifungal action of the EOs yielded some interesting findings. S. dolomitica and S. somalensis EOs appeared active against Mucor sp. and T. roseum, respectively. These fungi are spoiling molds of foodstuff, so a possible use of the investigated EOs as food additives could be suggested. Small amounts of both EOs appeared to be active against M. gypseum, a dermatophyte responsible for ringworm both in animals and in humans. Furthermore, this mold is reported to possess a limited sensitivity versus conventional antimycotic drugs such as griseofulvin [14] and itraconazole [15]. For this reason these compounds could be evaluated as active ingredients of shampooing/lotion formulations intended for local application. The major components of both examined EOs such as 1,8 cineole, bornyl acetate, $\beta$-caryophyllene, $\alpha$-pinene, camphor were shown to possess antifungal activity [16], in particular EOs containing such components were effective against Fusarium spp. [17], Heterobasidion parviporum [18] and EOs from plants rich in bornyl acetate and $\alpha$-pinene showed antimycotic action $[19,20]$.

$\beta$-Caryophyllene is reported to have a fungicide activity versus Aspergillus niger and Aspergillus fumigatus [21], while 1,8 cineole has showed high MICs against Microsporum canis and M. gypseum [15]. The EOs used in the present study did not give good results when assayed against aspergilli, in contrast with a previous report referred to S. sclarea, while the lack of activity against Candida yeasts was confirmed [11]. However, data from the literature showed that S. officinalis was active against yeasts, aspergilli and dermatophytes [22], while Salvia fruticosa was highly effective versus dermatophytes [23] and phytopathogenic fungi [24].

Some papers are referred to EOs from plants in which such active principles were present in higher amounts [17]. Being represented in amounts lower than $20 \%$, they could be responsible for their moderate antifungal effect. 
Sage EOs have been proposed for antimicrobial treatments [3]. However, several species of the genus Salvia occur worldwide and their different chemical compositions have been demonstrated in several studies [25]. These differences could be due to several factors, including their habitat, cultivation methods and extraction procedures. Thus the antimicrobial activity of different botanical species should be thoroughly verified, according to their chemotype.

\section{Material and Methods}

\subsection{Essential Oils}

S. dolomitica Codd (Voucher number PI010354) and S. somalensis Vatke (Voucher number PI010355) belong to a collection coming from the CREA (Centro di ricerca Orticoltura e Florovivaismo) located in Sanremo (Liguria, Italy) and collected in 2015. Both the Salvia spp. were vegetatively propagated, planted and grown under uniform conditions. The aerial parts were dried and hydrodistillated for $2 \mathrm{~h}$ to obtain the respective EOs, that were maintained at $4{ }^{\circ} \mathrm{C}$ in dark glass vials and microbiologically tested for quality control before use.

\subsection{Gas Chromatography-Mass Spectrometry Analysis}

The GC-MS analysis and the identification of the constituents in both EOs were performed following a previously reported protocol [26].

\subsection{Antibacterial Activity}

\subsubsection{Bacterial Strains}

Both EOs were tested against the following bacterial species: S. aureus, S. pseudointermedius, P. aeruginosa, E. coli, S. canis, S. pyogenes, K. pneumoniae, P. mirabilis. All the strains have been previously isolated from clinical specimens collected from dogs with different pathologies, such as infection of ear, skin and genitourinary tract.

\subsubsection{Agar Disk Diffusion Method}

The antibacterial activity of both EOs was determined with the Agar disk diffusion method following the procedures described by Clinical and Laboratory Standards Institute (CLSI) [27] and with some modifications as previously described [28]. Each EO was tested at a 1:10 dilution in dimethyl sulfoxide (DMSO, Oxoid Ltd.). An absorbent paper disc impregnated with $10 \mu \mathrm{L}$ of DMSO was used as negative control. Paper discs impregnated with amikacin $(30 \mu \mathrm{g})$, amoxycillin-clavulanic acid $(30 \mu \mathrm{g})$, cefotaxime $(30 \mu \mathrm{g})$, tetracycline $(30 \mu \mathrm{g})$ (Oxoid Ltd.), respectively, were used as positive controls. The results of the bacterial in vitro sensitivity to antibiotics were interpreted as indicated by the CLSI [29]. All tests were performed in triplicate.

\subsubsection{Minimum Inhibitory Concentration}

Each bacterial strain was also submitted to MIC determination. MIC was evaluated by the broth microdilution method following the protocol previously reported [28]. The test was performed in a total volume of $200 \mu \mathrm{L}$ with final EOs concentrations of 16.26 to $2.03 \mathrm{mg} / \mathrm{mL}$ for S. dolomitica, 17.04 to $2.13 \mathrm{mg} / \mathrm{mL}$ for $\mathrm{S}$. somalensis. The same assay, carried out in BHIB was simultaneously performed for bacterial growth control (tested bacteria and BHIB) and sterility control (tested oil and BHIB). All tests were performed in triplicate. 


\subsection{Antifungal Activity}

\subsubsection{Fungal Strains}

Isolates of dermatophytes (M. canis, M. gypseum, Trichophyton mentagrophytes) and yeasts (Candida albicans and Candida krusei) were obtained from animal specimens. Other molds such as A. niger, Aspergillus flavus, Mucor sp. and T. roseum were isolated from environmental sources and were used for in vitro sensitivity assays. These fungi were selected for their impact on both animal and human health. In particular dermatophytes are keratinophilic and keratinolytic molds able to infect both animal and human teguments and annexes, responsible for ringworm. C. albicans and C. krusei are endo- and esosaprophytic yeasts, respectively, known as causative agents of superficial mycoses (stomatitis, vulvovaginitis) in immunocompetent hosts, and deep generalized life threatening infections in immunocompromised patients. A. niger, A. flavus, Mucor sp. and T. roseum are environmental food-spoiling molds. Furthermore A. flavus, and T. roseum are toxigenic fungi, able to elaborate secondary metabolites, such as aflatoxins and trichothecenes on foodstuff, which can cause severe chronic lesions in consumers. All molds (dermatophytes and environmental fungi) were maintained on Potato Dextrose Agar at $-20^{\circ} \mathrm{C}$, while yeasts were stored into sterile distilled water.

\subsubsection{Microdilution Test}

The antimycotic activity of EOs was essayed by a microdilution test carried out as recommended by Clinical and Laboratory Standards Institute $\mathrm{M}_{3} \mathrm{~A}_{2}$ [30] for molds and Clinical and Laboratory

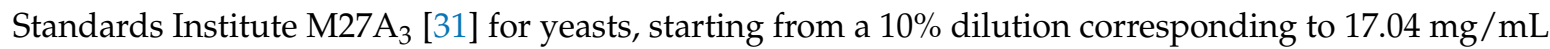
(S. somalensis) and $16.26 \mathrm{mg} / \mathrm{mL}$ (S. dolomitica), respectively, and $7.5 \%, 5 \%, 3 \%, 2 \%$ and $1 \%$ further dilutions were achieved. All assays were performed in triplicate. Controls were also achieved using conventional antifungal drugs. Clinical breakpoint of standard drugs referred to Aspergillus and Candida species provided by CLSI were taken into consideration.

\section{Conclusions}

Our results show that $S$. somalensis and S. dolomitica EOs, largely employed in cosmetic and perfume industry, have not relevant both antifungal and antibacterial activities if compared to conventional drugs. So these EOs cannot be considered promising candidates not even against fungal organisms with lower sensitivity such as M. gypseum, Mucor sp. and T. roseum.

Author Contributions: V.V.E. and F.M. conceived and designed the experiments; S.N., F.B., S.G. and B.R. performed the experiments; S.N., C.D. and L.P. analyzed the data; V.V.E., F.M., S.G. and L.P. wrote the paper.

Conflicts of Interest: The authors declare no conflict of interest.

\section{References}

1. Bassolino, L.; Giacomelli, E.; Giovanelli, S.; Pistelli, L.; Cassetti, A.; Damonte, G.; Bisio, A.; Ruffoni, B. Tissue culture and aromatic profile in Salvia dolomitica Codd. Plant Cell Tissue Organ Cult. 2015, 121, 83-95. [CrossRef]

2. Kamatou, G.P.; Makunga, N.P.; Ramogola, W.P.; Viljoen, A.M. South African Salvia species: A review of biological activities and phytochemistry. J. Ethnopharmacol. 2008, 119, 664-672. [CrossRef] [PubMed]

3. Kamatou, G.P.P.; van Vuuren, S.F.; van Heerden, F.R.; Seaman, T.; Viljoen, A.M. Antibacterial ad antimycobacterial acitivities of South African Salvia species and isolated compounds from S. chamelaegnea. S. Afr. J. Bot. 2007, 73, 552-557. [CrossRef]

4. Villa, C.; Trucchi, B.; Bertoli, A.; Pistelli, L.; Parodi, A.; Bassi, A.M.; Ruffoni, B. Salvia somalensis essential oil as a potential cosmetic ingredient: Solvent-free microwave extraction, hydrodistillation, GC-MS analysis, odor evaluation and in vitro cytotoxicity assays. Int. J. Cosmet. Sci. 2009, 31, 55-61. [CrossRef] [PubMed]

5. Caser, M.; Ruffoni, B.; Scariot, V. Screening for drought tolerance in Salvia spp. and Helichrysum petiolare: A way to select low maintenance ornamental plants. Acta Hortic. 2012, 953, 239-246. [CrossRef] 
6. Cervelli, C.; Capponi, A.; Mascarello, C.; Ruffoni, B.; Del Gaudio, C. New species and cultivars of Salvia as ornamental pot plant. Acta Hortic. 2013, 1000, 35-42. [CrossRef]

7. Fisher, V.L. Indigenous Salvia Species-An Investigation of the Antimicrobial Activity, Antioxidant Activity and Chemical Composition of Leaf Extract. Ph.D. Thesis, Faculty of Health Science, University of Witwatersrand, Johannesburg, South Africa, 2005.

8. Kamatou, G.P.P.; Viljoen, A.M.; Figueiredo, A.C.; Tilney, P.M.; Van Zyl, R.L.; Barroso, J.G.; Pedro, L.G.; Van Vuuren, S.F. Trichomes, Essential oil composition and biological activities of Salvia albicaulis Benth. and S. dolomitica Codd, two species from the Cape region of South Africa. S. Afr. J. Bot. 2007, 73, 102-108. [CrossRef]

9. Simsek, M.; Duman, R. Investigation of effect of 1,8-cineole on antimicrobial activity of chlorhexidine gluconate. Pharmacogn. Res. 2017, 9, 234-237. [CrossRef] [PubMed]

10. Dahham, S.S.; Tabana, Y.M.; Iqbal, M.A.; Ahamed, M.B.; Ezzat, M.O.; Majid, A.S.; Majid, A.M. The Anticancer, Antioxidant and Antimicrobial Properties of the Sesquiterpene $\beta$-Caryophyllene from the Essential Oil of Aquilaria crassna. Molecules 2015, 20, 11808-11829. [CrossRef] [PubMed]

11. Ebani, V.V.; Nardoni, S.; Bertelloni, F.; Najar, B.; Pistelli, L.; Mancianti, F. Antibacterial and antifungal activity of essential oils against pathogens responsible for otitis externa in dogs and cats. Medicines 2017, 4, 21. [CrossRef] [PubMed]

12. Khalil, R.; Li, Z.G. Antimicrobial activity of essential oil of Salvia officinalis L. collected in Syria. Afr. J. Biotechnol. 2011, 10, 8397-8402.

13. Coisin, M.; Burzo, I.; Stefan, M.; Rosenhech, E.; Zamfirache, M.M. Chemical composition and antibacterial activity of essential oils of three Salvia species widespread in eastern Romania. Analele Ştiinţifice ale Universităţii Al. I. Cuza" Iaşi s. II a. Biol. Veg. 2012, 58, 51-58.

14. Nardoni, S.; Mugnaini, L.; Papini, R.A.; Fiaschi, M.; Mancianti, F. Canine and feline dermatophytosis due to Microsporum gypseum: A retrospective study of clinical data and therapy outcome with griseofulvin. J. Mycol. Med. 2013, 23, 164-167. [CrossRef] [PubMed]

15. Nardoni, S.; Giovanelli, S.; Pistelli, L.; Mugnaini, L.; Profili, G.; Pisseri, F.; Mancianti, F. In vitro activity of twenty commercially available, plant-derived essential oils against selected dermatophyte species. Nat. Prod. Commun. 2015, 10, 1473-1478. [PubMed]

16. Hossain, M.A.; Ismailb, Z.; Rahman, A.; Kang, S.C. Chemical composition and anti-fungal properties of the essential oils and crude extracts of Orthosiphon stamineus Bent. Ind. Crops Prod. 2008, 27, 328-334. [CrossRef]

17. Sampietro, D.A.; Gomez, A.L.; Jimenez, C.M.; Lizarraga, E.F.; Ibatayev, Z.A.; Suleimen, Y.M.; Catalãn, C.A. Chemical composition and antifungal activity of essential oils from medicinal plants of Kazakhstan. Nat. Prod. Res. 2017, 31, 1464-1467. [CrossRef] [PubMed]

18. Kusumoto, N.; Zhao, T.; Swedjemark, G.; Ashitani, T.; Takahashi, K.; Borg-Karlson, A.K. Antifungal properties of terpenoids in Picea abies against Heterobasidion parviporum. For. Pathol. 2014, 44, 353-361. [CrossRef]

19. Hong, E.J.; Na, K.J.; Choi, I.G.; Choi, K.C.; Jeung, E.B. Antibacterial and antifungal effects of essential oils from coniferous trees. Biol. Pharm. Bull. 2004, 27, 863-866. [CrossRef] [PubMed]

20. Mirzania, F.; Sarrafi, Y.; Farimani, M.M. Comparison of chemical composition, antifungal antibacterial activities of two populations of Salvia macilenta Boiss. Essential oil. Rec. Nat. Prod. 2018, 12, 385-390. [CrossRef]

21. Selestino Neta, M.C.; Vittorazzi, C.; Guimarães, A.C.; Martins, J.D.; Fronza, M.; Endringer, D.C.; Scherer, R. Effects of $\beta$-caryophyllene and Murraya paniculata essential oil in the murine hepatoma cells and in the bacteria and fungi 24-h time-kill curve studies. Pharm. Biol. 2017, 55, 190-197. [CrossRef] [PubMed]

22. Abu-Darwish, M.S.; Cabral, C.; Ferreira, I.V.; Gonçalves, M.J.; Cavaleiro, C.; Cruz, M.T.; Al-bdour, T.H.; Salgueiro, L. Essential oil of common sage (Salvia officinalis L.) from Jordan: Assessment of safety in mammalian cells and its antifungal and anti-inflammatory potential. Biomed. Res. Int. 2013, 53, 8940. [CrossRef]

23. Ali-Shtayeh, M.S.; Abu Ghdeib, S.I. Antifungal activity of plant extracts against dermatophytes. Mycoses 1999, 42, 665-672. [CrossRef] [PubMed]

24. Pitarokili, D.; Tzakou, O.; Loukis, A.; Harvala, C. Volatile metabolites from Salvia fruticosa as antifungal agents in soilborne pathogens. J. Agric. Food Chem. 2003, 51, 3294-3301. [CrossRef] [PubMed] 
25. Longaray Delamare, A.P.; Moschen-Pistorello, I.T.; Atti-Serafini, L.; Echeverrigaray, S. Antibacterial activity of the essential oils of Salvia officinalis L. and Salvia triloba L. cultivated in South Brazil. Food Chem. 2007, 100, 603-608. [CrossRef]

26. Giovanelli, S.; Giusti, G.; Cioni, P.L.; Minissale, P.; Ciccarelli, D.; Pistelli, L. Aroma profile and essential oil composition of Rhus coriaria fruits from four Sicilian sites of collection. Ind. Crops Prod. 2017, 97, 166-174. [CrossRef]

27. Clinical and Laboratory Standards Institute (CLSI). Performance Standards for Antimicrobial Disk Susceptibility Tests, 11th ed.; CLSI: Wayne, PA, USA, 2012; p. M02-A11.

28. Ebani, V.V.; Nardoni, S.; Bertelloni, F.; Giovanelli, S.; Rocchigiani, G.; Pistelli, L.; Mancianti, F. Antibacterial and antifungal activity of essential oils against some pathogenic bacteria and yeast shed from poultry. Flavour Fragr. J. 2016, 31, 302-309. [CrossRef]

29. CLSI/National Committee for Clinical Laboratory Standards. Performance Standards for Antimicrobial Susceptibility Testing; Twelfth International Supplement; NCCS: Wayne, PA, USA, 2002; pp. M100-M112.

30. Clinical and Laboratory Standards Institute (CLSI). Reference Method for Broth Dilution Antifungal Susceptibility Testing of Filamentous Fungi, 2nd ed.; CLSI: Wayne, PA, USA, 2008; p. M38-A2.

31. Clinical and Laboratory Standards Institute (CLSI). Reference Method for Broth Dilution Antifungal Susceptibility Testing of Yeasts, 3rd ed.; CLSI: Wayne, PA, USA, 2008; p. M27-A3.

Sample Availability: Samples of the essential oils of both Salvia somalensis and Salvia dolomitica are available from the authors.

(C) 2018 by the authors. Licensee MDPI, Basel, Switzerland. This article is an open access article distributed under the terms and conditions of the Creative Commons Attribution (CC BY) license (http:/ / creativecommons.org/licenses/by/4.0/). 